\title{
AGE AND PROVENANCE OF THE UPPER CRETACEOUS TO PALEOCENE VALDEZ GROUP OF THE CHUGACH TERRANE FROM THE RICHARDSON HIGHWAY AND NORTHERN PRINCE WILLIAM SOUND, ALASKA
}

NICHOLAS GROSS ALMONTE, Carleton College

Research Advisors: Cameron Davidson, Carleton College and John I. Garver, Union College

\section{INTRODUCTION}

The age and provenance of the southern Alaskan Campanian to Paleocene Valdez Group of the Chugach terrane and its relationship with the younger outboard Paleocene to Eocene Orca Group of the Prince William terrane is poorly understood but an important component of the Cordilleran collage (Plafker et al., 1994). The Valdez and Orca Groups are both part of the Chugach-Prince William terrane (CPW), which is a thick accretionary complex that extends $2200 \mathrm{~km}$ along the southern Alaskan margin (Fig. 1; Cowan, 2003). The deep-water turbidites of these terranes are quartzofeldspathic and volcanic-lithic sandstones and basaltic rocks (Dumoulin, 1987; Plafker et al., 1994). The CPW is intruded by near-trench plutons of the Sanak-Baranof belt (Davidson and Garver, 2017) and are believed to be related to a slab window that formed during subduction of Kula-Farallon or KulaResurrection spreading ridges (Marshak and Karig, 1977; Delong et al., 1978; Moore et al., 1983; Kusky et al., 1997a; Bradley et al., 2003; Haeussler et al., 2003). There are two hypotheses for the formation of the CPW along the North American Cordilleran margin: 1) either the CPW terrane formed in situ by subduction of the Resurrection plate (Haeussler et al. 2003); or 2) the rocks formed in the Pacific Northwest or California and were transported at least $2000 \mathrm{~km}$ along coastwise strike-slip fault systems (Cowan, 2003; Garver and Davidson, 2015).

This study is an investigation into the age and provenance of the Valdez Group and its relationship with the Orca Group in the central Chugach Mountains using detrital zircon U-Pb dates. New detrital zircon $\mathrm{U}-\mathrm{Pb}$ dates and their grain-age distributions from the Valdez and Orca Group turbidites are combined with dates from Kochelek et al. (2011), Amato et al. (2013), and Davidson and Garver (2017) and then synthesized to understand the difference in age between the units and provenance. New and existing U-Pb dates indicate maximum depositional ages (MDA) of the Valdez Group are concentrated in three groups: $84-78 \mathrm{Ma}$, 74-65 Ma, and 62-60 Ma. The youngest group of MDAs are age-correlative with the Orca Group but were collected from rocks in areas mapped as Valdez Group, indicating that either Orca Group rocks occur in the Valdez Group or the youngest Valdez Group rocks are stratigraphically equivalent to those of the oldest Orca Group. If the latter, the Valdez Group is not Campanian to Maastrichtian in age as has been traditionally viewed (Plafker et al., 1994) but is Upper Cretaceous to Paleocene and in part correlative to the lowest part of the Orca Group.

\section{GEOLOGIC SETTING}

\section{Chugach terrane}

The Chugach terrane is composed of 1) Late Triassic to Jurassic glaucophane greenschist with local blueschist facies as young as Early Cretaceous (Day et al., 2016), 2) the Early Triassic to Early Cretaceous McHugh Complex, and 3) the Late Cretaceous Valdez Group (Plafker et al., 1994; Amato et al., 2013). The McHugh Complex is divided into two assemblages based on distinctive lithologies and MDAs: the 101-91 Ma McHugh Creek assemblage consisting of massive 


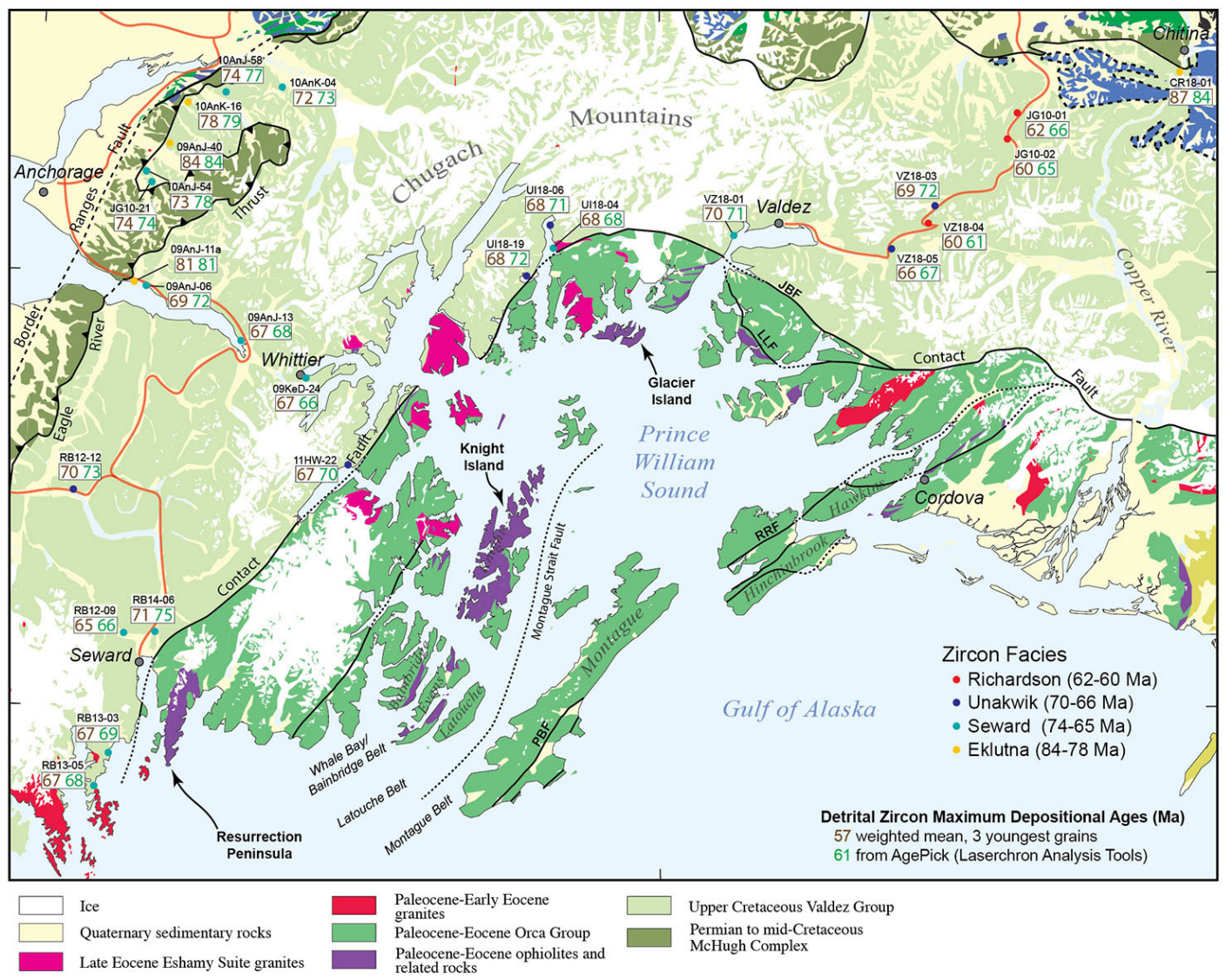

Figure 1. Geologic map of Prince William Sound, Alaska (modified from Bradley and Miller, 2006).

sandstones and conglomerates, and the 169-156 Ma Potter Creek assemblage consisting of chert, argillite, and volcanic rocks (Amato and Pavlis, 2010; Amato et al., 2013). The age of the Valdez Group has been previously constrained by sparse Inoceramus fossils from Turnagain Arm near Anchorage, indicating that the Valdez Group is no older than Late Cretaceous in age (Moffit, 1954). The Coast Mountains in British Columbia are inferred to be the primary source of the flysch (Plafker et al., 1994; Haeussler et al., 2006).

\section{Prince William terrane}

The Prince William (PW) terrane is composed of the Paleocene to Eocene Orca Group (Dumoulin, 1987; Plafker et al., 1994; Garver and Davidson, 2015). The Orca Group has a more diverse lithology than the Valdez Group with abundant volcanic rocks including breccias, sills, dikes, and pillows, all with a basaltic composition, and these rocks have experienced a lesser degree of metamorphism (Plafker and MacNiel, 1966).

\section{Border Ranges Fault System}

The Border Ranges fault (BRF) system is the tectonic boundary between the Chugach terrane and the inboard units of the Wrangellia composite terrane (MacKevett and Plafker, 1974; Pavlis, 1982; Pavlis et al., 1988, 2003; Pavlis and Crouse, 1989; Plafker et al., 1989, 1994; Cowan, 2003; Roeske et al., 2003; Pavlis and Roeske, 2007). If there has been coastwise translation of the CPW, it most likely was accommodated on the BRF (Cowan, 2003). The BRF system is responsible for underthrusting the Chugach terrane a horizontal distance of at least $40 \mathrm{~km}$ beneath the Wrangellia composite terrane (Plafker et al., 1994).

\section{Contact Fault}

Current mapping separates the older Valdez Group of the Chugach terrane from the younger Orca Group of the Prince William terrane along the Contact fault system (Bol and Roeske, 1993; Plakfer et al., 1994; Wilson et al., 2015). The Contact fault is a strike-slip and dip-slip fault between the Chugach and Prince 


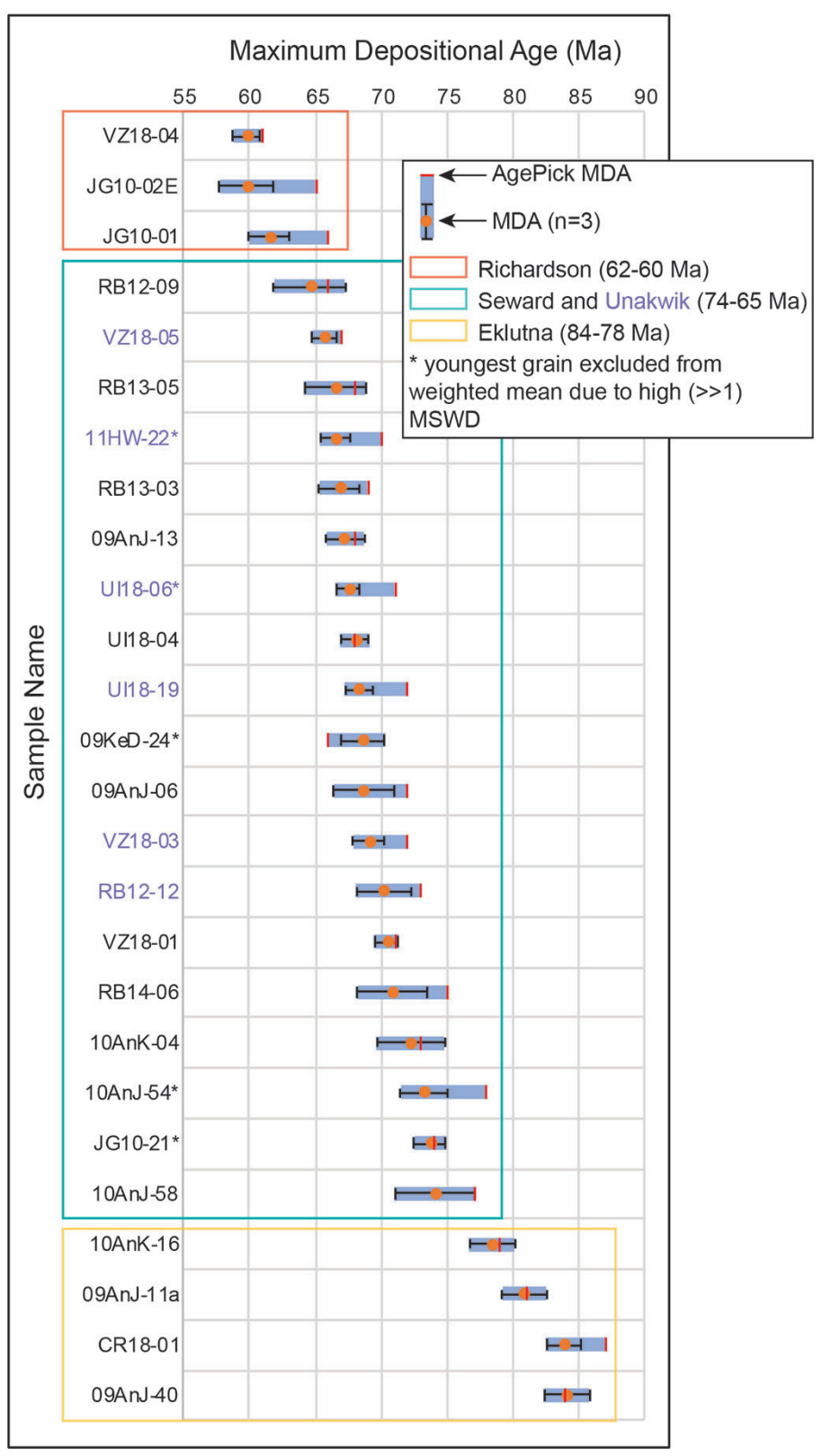

Figure 2. Maximum depositional ages (MDAs) of Valdez Group turbidites in Prince William Sound. MDA $(n=3)$ is the weighted mean of the three youngest coherent zircons from a sample, and AgePick MDA was determined using the AgePick macro of Gehrels (2012). Blue bars show the range of uncertainty of the MDA for a sample.

William terranes and is locally called the Jack Bay fault in northern Prince William Sound. Bol and Roeske (1993) proposes the Contact fault is a strikeslip fault between the terranes, while Plafker et al. (1994) believes the Contact fault places the Orca Group underneath the Valdez Group. Malik et al. (2019), however, suggests the Contact fault may not actually be a terrane bounding fault. The Contact fault cuts rocks in an east-west arc through Valdez Arm and
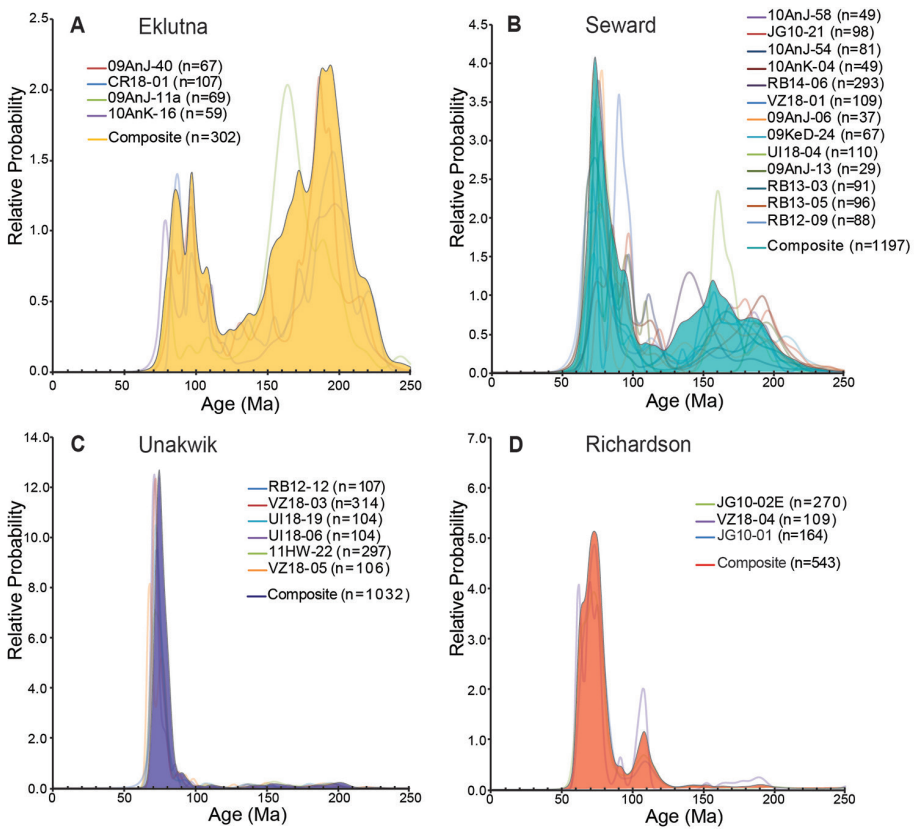

Figure 3. Probability density functions (PDFs) of detrital zircon $\mathrm{U} / \mathrm{Pb}$ ages for the four zircon facies identified in the Valdez Group. Filled PDFs are composites of all samples in a facies. Legends are organized from oldest to youngest MDA in the group. (A) Eklutna facies with MDAs between 84-78 Ma, (B) Seward facies with MDAs between 74-65 Ma, (C) Unakwik facies with MDAs between 70-66 Ma, and (D) Richardson facies with MDAs between 62-60 Ma.

Unakwik Inlet in our study area.

\section{METHODS}

$\mathrm{U}-\mathrm{Pb}$ ages of detrital zircons were determined from ten sandstone samples of the Valdez Group from northern Prince William Sound and the Richardson Highway as part of this project. For this study, zircon crystals were extracted from our samples with standard methods of crushing, grinding, Rogers Table, heavy liquids, and Frantz magnetic separation. Polished detrital zircons were then dated by $\mathrm{U}-\mathrm{Pb}$ technique at the Arizona LaserChron Center with laser ablation inductively coupled plasma mass spectrometry (LA-ICP-MS) using standard methods to determine their age and provenance. Zircons were randomly chosen for analysis of 100 or 300 grains per sample.

\section{RESULTS}

$\mathrm{U}-\mathrm{Pb}$ data were collected from a total of 1,063 zircon grains from eight sandstone samples of the Valdez Group from near Chitina, along the Richardson Highway, and northern Prince William Sound. Our 
project contributes to a total of 3,074 grains dated (26 samples) from the Valdez Group. We exclude some published ages of the Valdez Group from Bradley et al. (2009), Kochelek et al. (2011), and Amato et al. (2013) due to poor precision (high $1 \sigma$ error and high MSWD) and a low number of zircons analyzed.

Valdez Group samples are dominated by Early to Late Jurassic, Early to Late Cretaceous, and Paleocene populations with their MDAs ranging from 84.1 to $59.8 \mathrm{Ma}$. We divide the range of MDAs into three different primary groups by reason of age breaks in the MDAs: 84-78 Ma, 74-65 Ma, and 62-60 Ma (Fig. 2). Each group of samples share similar grain-age distributions and is supported by the KolmogorovSmirnoff (K-S) test where the p-value between samples in the group is greater than 0.05 which corresponds to $95 \%$ confidence that the samples are not statistically different (Gehrels, 2012). Some samples fail the K-S test but are still considered part of a group because of similarities in grain-age distribution and MDA.

The oldest group, the Eklutna facies, includes previously published samples from Mount Magnificent, Turnagain Arm, and Eklutna River near

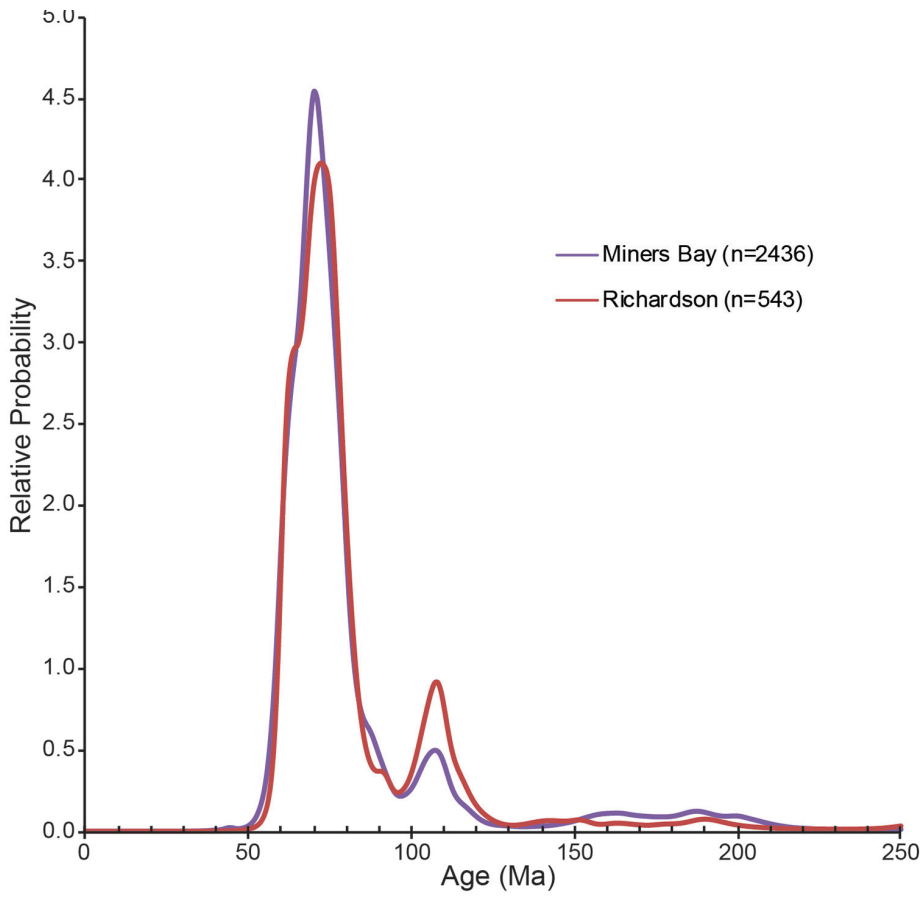

Figure 4. Composite probability density functions of the Richardson facies of the Valdez Group and Miners Bay facies of the Orca Group.

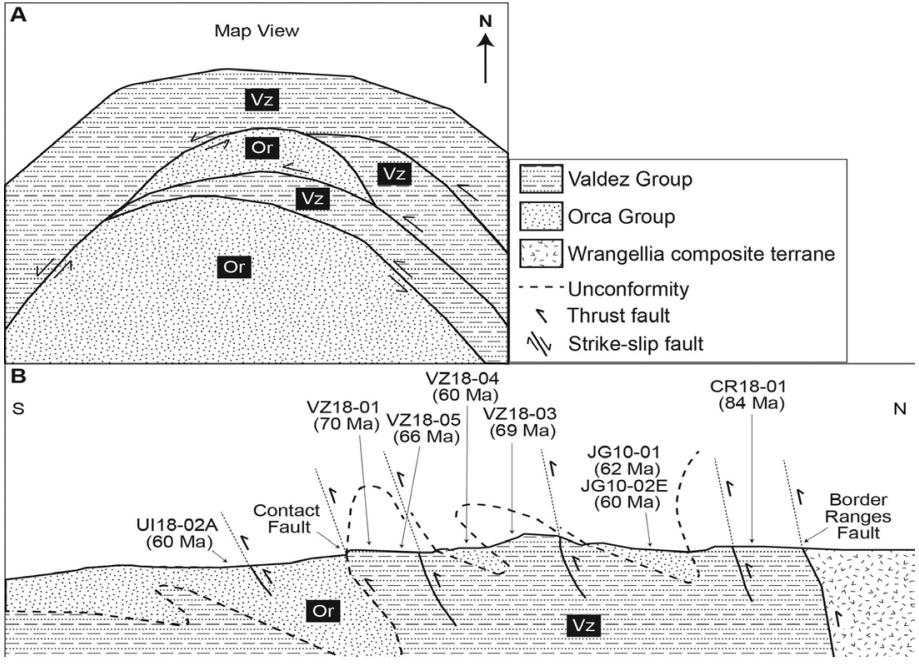

Figure 5. Two possible structural explanations for the occurrence of the young Richardson facies in the Valdez Group. A) The Paleocene rocks are correlative to the Orca Group and occur in the Valdez Group as structural slices. B) The Paleocene rocks were unconformably deposited on top of the Valdez and subsequently folded into the Valdez Group.

Anchorage and one from our study along the Copper River near Chitina (Fig. 1). These four samples (09AnJ-11a, 09AnJ-40, 10AnK-16, and CR18-01) have similar Late Cretaceous populations between 97 and $79 \mathrm{Ma}$ and Early to Middle Jurassic populations between 197 and $164 \mathrm{Ma}$ (Fig. 3A) with MDAs between 84-78 Ma. All samples share Precambrian detrital zircon grains with peaks at $\sim 1465 \mathrm{Ma}, \sim 1800$ $\mathrm{Ma}, \sim 1980 \mathrm{Ma}$, and $\sim 2705 \mathrm{Ma}$. All samples in this group pass the $\mathrm{K}-\mathrm{S}$ test.

The middle group is the largest and includes nineteen samples: 09AnJ-06, 09AnJ-13, 09KeD-24, 10AnJ54, 10AnJ-58, 10AnK-04, 11HW-22, JG10-21, RB12-09, RB12-12, RB13-03, RB13-05, RB14-06, UI18-04, UI18-06, UI18-19, VZ18-01, VZ18-03, and VZ18-05 (Fig. 1). The middle group is split into two sub-groups based on grain-age distribution. One sub-group, the Seward facies, has thirteen samples that have pronounced Early to Late Jurassic and Early Cretaceous populations between 192 and $140 \mathrm{Ma}$ with MDAs between 74-65 Ma (Fig. 3B). This subgroup's Precambrian grains have a wide range of ages between $\sim 560$ to $\sim 2760 \mathrm{Ma}$. The other sub-group, the Unakwik facies, includes six samples: 11HW-22, RB12-12, UI18-06, UI18-19, VZ18-03, and VZ18-05 (Fig. 3C). The Unakwik facies, with MDAs between 70-66 Ma, is remarkably uniform and is dominated by Late Cretaceous zircons between 76-68 Ma and do not 
have older populations like the Seward facies. These samples share many Precambrian peaks between $\sim 1730$ to $\sim 2310 \mathrm{Ma}$ and between $\sim 2550$ to $\sim 2740 \mathrm{Ma}$. VZ18-05 is the only sample in the sub-group that fails the K-S test.

The youngest group, the Richardson facies, includes three samples (JG10-01, JG10-02E, and VZ18-04) collected from rocks mapped as the Valdez Group along the Richardson Highway (Fig. 1) and are dominated by zircons with Late Cretaceous (72$70 \mathrm{Ma}$ ) and Early Cretaceous (109-106 Ma) peak ages (Fig. 3D) with MDAs between 62-60 Ma. The samples in this group also have a wide age range of Precambrian grains, but they all share peaks between $\sim 1775$ to $\sim 2050 \mathrm{Ma}$. VZ18-04 fails the K-S test for this group, probably because of the large Cretaceous peak at $108 \mathrm{Ma}$ (Fig. 3D).

\section{DISCUSSION}

Grain-age distributions of the Valdez Group are dominated by Paleocene and Cretaceous peaks, possibly originating from an active and partially dissected Late Cretaceous to Paleocene volcanic arc (Garver and Davidson, 2015). Many samples also have Jurassic populations which may come from meta-plutonic basement rocks built on the volcanic arc (Garver and Davidson, 2015). The grain-age distribution of the CPW terrane is strikingly similar to that of the Coast Mountains Batholith Complex (CMB) in British Columbia (Haeussler et al., 2006; Garver and Davidson, 2015), suggesting that the CPW terrane may have formed farther south and adjacent to the CMB (Garver and Davidson, 2015).

The MDAs of the Eklutna facies (84-78 Ma), Seward facies (74-65 Ma) and Unakwik facies (70-66 Ma) suggest that these rocks were deposited in the Cretaceous and are consistent with previous age estimates (Plafker et al., 1994). However, the Richardson facies (62-60 $\mathrm{Ma})$ is Paleocene in age and is age-correlative with the Orca Group. A comparison of the Richardson facies of the Valdez Group with the Miners Bay facies (which includes the three samples that comprise the Richardson facies) of the Orca Group (Fisher, 2019) shows that these rocks are nearly identical (Figs. 1\&4). A key question is the stratigraphic alliance of this young facies (62-60 Ma) in the Valdez Group. Samples from the Richardson facies were collected 50 to 100 $\mathrm{km}$ away from the Contact fault and along Richardson Highway, an area long-mapped as Valdez Group (Fig. 1). We have two options for the occurrence of Orca Group age-correlative samples in areas mapped as the Valdez Group: 1) the Richardson facies is part of the Valdez Group and is stratigraphically equivalent to the oldest Orca Group (Miners Bay facies); or 2) the Richardson facies is part of the Orca Group and occurs in the Valdez Group as structural slices (Fig. 5A) or was deposited unconformably on top of the Valdez and subsequently folded into the Valdez Group (Fig. 5B).

\section{CONCLUSIONS}

Detrital zircon U-Pb ages from turbidites of the Valdez Group of the Chugach terrane in Prince William Sound demonstrate the complex relationship between the Valdez Group with the outboard turbidites of the Paleocene-Eocene Orca Group. New detrital zircon $\mathrm{U}-\mathrm{Pb}$ data, however, suggests that the Valdez Group is Upper Cretaceous to Paleocene in age. MDAs of the Valdez Group form three groups: 84-78 Ma, 74$65 \mathrm{Ma}$ and 62-60 Ma. The youngest MDA group, the Richardson facies, overlaps in age with the Miners Bay facies from the Orca Group (Fisher et al., 2019). This study supports the conclusions of Malik et al. (2019) that the Contact fault system may not be a terrane boundary (Malik et al., 2019).

\section{ACKNOWLEDGEMENTS}

The material from this study is based upon field work and analyses funded by the National Science Foundation (NSF) under NSF Grant "Collaborative Research: RUI: Translation and accretion of the Yakutat microplate and Prince William terrane, Alaska" No. EAR-1727991 (to C. Davidson, Carleton College) and No. EAR-1728013 (to J.I. Garver, Union College). We were also funded by the Keck Geology Consortium Grant "Geology of the Chugach-Prince William terrane in northern Prince William Sound" (to J.I. Garver, Union College) and partly funded by NSF Grant No. EAR-1659322 (to Keck Geology Consortium). I would also like to acknowledge the Arizona LaserChron Center funded by NSF-EAR Grant No. 1649254 who made zircon analysis possible. I would like to thank my project advisors Dr. Cameron 
Davidson and Dr. John I. Garver for the opportunity to participate in this Keck REU project. Lastly, I would like to thank the other students in the research group for their diligent work on this project: W. Fisher, V. Garcia, A. Malik, C. Noseworthy, and M. Pope.

\section{REFERENCES}

Amato, J.M., and Pavlis, T.L., 2010, Detrital zircon ages from the Chugach terrane, southern Alaska, reveal multiple episodes of accretion and erosion in a subduction complex: Geology, v. 38, p. 459462.

Amato, J.M., Pavlis, T.L., Clift, P.D., Kochelek, E.J., Hecker, J.P., Worthman, C.M., and Day, E.M., 2013, Architecture of the Chugach accretionary complex as revealed by detrital zircon ages and lithologic variations: evidence for Mesozoic subduction erosion in southcentral Alaska: Geol. Soc. Am. Bull. 125:1891-1911.

Bol, A.J., and Roeske, S.M., 1993, Strike-slip faulting and block rotation along the contact fault system, eastern Prince William Sound, Alaska: Tectonics $12: 49-62$

Bradley, D.C., Kusky, T.M., Haeussler, P.J., Goldfarb, R.J., Miller, M.L., Dumoulin, J.A., Nelson, S. S., and Karl, S.M., 2003, Geologic signature of early Tertiary ridge subduction in Alaska. In Sisson, V. B., Roeske, S., and Pavlis, T. L., eds., Geology of a transpressional orogen developed during ridgetrench interaction along the North Pacific margin: Geol. Soc. Am. Spec. Pap. 371:19-49.

Bradley, D.C., and Miller, M.L., 2006, Field guide to south-central Alaska's accretionary complex, Anchorage to Seward: Anchorage, Alaska Geological Society, 32 p.

Bradley, D., Haeussler, P., O'Sullivan, P., Friedman, R., Till, A., Bradley, D. and Trop, J., 2009, Detrital zircon geochronology of Cretaceous and Paleogene strata across the south-central Alaskan convergent margin (No. 1760-F): US Geological Survey, $36 \mathrm{p}$.

Cowan, D.S., 2003, Revisiting the Baranof-Leech River hypothesis for early Tertiary coastwise transport of the Chugach-Prince William terrane: Earth and Planetary Science Letters, v. 213, p. 463-475.

Davidson, C. and Garver, J., 2017, Age and origin of the Resurrection Ophiolite and associated turbidites of the Chugach-Prince William terrane, Kenai Peninsula, Alaska: The Journal of Geology, v. 125, p. 681-700.

Day, E.M., Pavlis, T.L., Amato, J.M., 2016, Detrital zircon ages indicate an Early Cretaceous episode of blueschist-facies metamorphism in southern Alaska: Implications for the Mesozoic paleogeography of the northern Cordillera: Lithosphere, v. 8, no. 5; p. 451-462.

Delong, S.E., Fox, P.J., and McDowell, F.W., 1978, Subduction of the Kula ridge at the Aleutian trench: Geol. Soc. Am. Bull. 89:83-95.

Dumoulin, J.A., 1987, Sandstone composition of the Valdez and Orca Groups, Prince William Sound, Alaska: U.S. Geological Survey Bulletin 1774, p. $1-37$.

Fisher, W.S., Pope, M.D., Malik, A.M., Garver, J.I., and Davidson, C., 2019, Zircon facies in the PaleoceneEocene Orca Group indicate a provenance link to the Chugach terrane, Prince William Sound, Alaska: Geological Society of America Abstracts with programs, v. 51, Portland, OR.

Garver, J., and Davidson, C., 2015, Southwestern Laurentian zircons in Upper Cretaceous flysch of the Chugach-Prince William terrane in Alaska: American Journal of Science, v. 315, p. 537-556.

Gehrels, G., 2012, Detrital Zircon U-Pb Geochronology: Current Methods and New Opportunities, in Tectonics of Sedimentary Basins: Recent Advances, C. Busby and A. Azor, editors, WileyBlackwell Publishing, p. 47-62.

Haeussler, P. J., Bradley, D.C., Wells, R.E., and Miller, M.L., 2003, Life and death of the Resurrection plate: Evidence for its existence and subduction in the northeastern Pacific in Paleocene-Eocene time: Geological Society of America Bulletin, v. 
115, p. $867-880$.

Haeussler, P.J., Gehrels, G.E., and Karl, S.M., 2006, Constraints on the age and provenance of the Chugach accretionary complex from detrital zircons in the Sitka Graywacke near Sitka, Alaska: U.S. Geol. Surv. Prof. Pap. 1709-F, 24 p.

Kochelek, E.J., Amato, J.M., Pavlis, T.L., and Clift, P.D., 2011, Flysch deposition and preservation of coherent bedding in an accretionary complex; detrital zircon ages from the Upper Cretaceous Valdez Group, Chugach Terrane, Alaska: Lithosphere, v. 3, no. 4; 4, p. 265-274.

Kusky, T.M., Bradley, D.C., and Haeussler, P., 1997a, Progressive deformation of the Chugach accretionary complex, Alaska, during a Paleogene ridge-trench encounter: J. Struct. Geol. 19:139157.

MacKevett, E., Jr., and Plafker, G., 1974, The Border Ranges fault in south-central Alaska: U.S. Geol. Surv. J. Res. 2:323-329.

Malik, A.M., Fisher, W.S., Gross Almonte, N., Garver, J.I., and Davidson, C., 2019, U-Pb dating of detrital zircon from turbidites of the Chugach and Prince William terranes in Prince William Sound, Alaska: Implications for the significance of the Contact fault system as a terrane boundary: Geological Society of America Abstracts with programs, v. 51, Portland, OR.

Marshak, R.S., and Karig, D.E., 1977, Triple junctions as a cause for anomalously near-trench igneous activity between the trench and volcanic arc: Geology 5:233-236.

Moffit, F.H., 1954, Geology of the Prince William Sound region, Alaska: U.S. Geological Survey Bulletin 989-E, p. 225-310, 1 sheet.

Moore, J.C., Byrne, T., Plumley, P.W., Reid, M., Gibbons, H., and Coe, R.S., 1983, Paleogene evolution of the Kodiak Islands, Alaska: consequences of ridge-trench interaction in a more southerly latitude: Tectonics, 2:265-293.

Pavlis, T.L., 1982, Origin and age of the Border Ranges fault of southern Alaska and its bearing on the late Mesozoic tectonic evolution of Alaska: Tectonics $1: 343-368$.

Pavlis, T.L., Monteverde, D.H., Bowman, J.R., Rubenstone, J.L., and Reason, M.D., 1988, Early Cretaceous near- trench plutonism in southern Alaska: atonalite- trondhjemite intrusive complex injected during ductile thrusting along the Border Ranges fault system: Tectonics 7:1179-1199.

Pavlis, T.L., and Crouse, G.W., 1989, Late Mesozoic strike slip movement on the Border Ranges fault system in the eastern Chugach Mountains, southern Alaska: J. Geophys. Res. Solid Earth 94(B4):4321-4332.

Pavlis, T.L., Marty, K., and Sisson, V.B., 2003, Eocene dextral strike slip within the Chugach terrane, southern Alaska: evidence from fabric studies along the Richardson Highway. In Sisson, V.B., Roeske, S., and Pavlis, T.L., eds., Geology of a transpressional orogen developed during ridgetrench interaction along the North Pacific margin: Geol. Soc. Am. Spec. Pap. 371:171-190.

Pavlis, T.L., and Roeske, S.M., 2007, The Border Ranges fault system, southern Alaska. In Ridgway, K. D., Trop, J. M., Glen, J. M. G., and O’Neill, J. M., eds., Tectonic growth of a collisional continental margin: crustal evolution of southern Alaska: Geol. Soc. Am. Spec. Pap. 431:95-127.

Plafker, G., and MacNeil, F.S., 1966, Stratigraphic significance of Tertiary fossils from the Orca Group in the Prince William Sound region, Alaska, in U.S. Geological Survey, Geological survey research 1966, Chapter B: U.S. Geological Survey Professional Paper 550-B, p. B62-B68.

Plafker, G., Nokleberg, W.J., and Lull, J.S., 1989, Bedrock geology and tectonic evolution of the Wrangellia, Peninsular, and Chugach terranes along the Trans-Alaska crustal transect in the Chugach Mountains and southern Copper River Basin, Alaska: J. Geophys. Res. Solid Earth 94(B4):4255-4295. 
Plafker, G., Moore, J.C., and Winkler, G.R., 1994, Geology of the southern Alaska margin, in Plafker, George, and Berg, H.C., eds., The geology of Alaska: Geological Society of America, DNAG Series, v. G-1, p. 389-449.

Roeske, S.M., Snee, L.W., and Pavlis, T.L., 2003, Dextral-slip reactivation of an arc-forearc boundary during Late Cretaceous-early Eocene oblique convergence in the northern Cordillera. In Sisson, V. B., Roeske, S., and Pavlis, T. L., eds., Geology of a transpressional orogen developed during ridge-trench interaction along the North Pacific margin: Geol. Soc. Am. Spec. Pap. 371: 141-169.

Wilson, F.H., Hults, C.P., Mull, C.G, and Karl, S.M, comps., 2015, Geologic map of Alaska: U.S. Geological Survey Scientific Investigations Map 3340, pamphlet 196 p., 2 sheets, scale 1:1,584,000, http://dx.doi.org/10.3133/sim3340. 